\title{
Article \\ Optimization and Kinetic Studies on Biodiesel Conversion from Chlorella vulgaris Microalgae Using Pyrrolidinium-Based Ionic Liquids as a Catalyst
}

\author{
Noorhafizah Hasanudin ${ }^{1}$, Noraini Abd Ghani ${ }^{1,2, *} \mathbb{D}$, Asyraf Hanim Ab Rahim ${ }^{1}$, Ninna Sakina Azman 1,2, \\ Nurhusna Aisyah Rosdi ${ }^{2}$ and Asiah Nusaibah Masri ${ }^{3,4}$
}

check for

updates

Citation: Hasanudin, N.; Abd Ghani, N.; Ab Rahim, A.H.; Azman, N.S.;

Rosdi, N.A.; Masri, A.N.

Optimization and Kinetic Studies on Biodiesel Conversion from Chlorella vulgaris Microalgae Using

Pyrrolidinium-Based Ionic Liquids as a Catalyst. Catalysts 2022, 12, 277.

https://doi.org/10.3390/catal12030277

Academic Editors: Vincenzo Vaiano,

Olga Sacco and Zheng Guo

Received: 10 November 2021

Accepted: 22 February 2022

Published: 1 March 2022

Publisher's Note: MDPI stays neutral with regard to jurisdictional claims in published maps and institutional affiliations.

Copyright: (c) 2022 by the authors. Licensee MDPI, Basel, Switzerland. This article is an open access article distributed under the terms and conditions of the Creative Commons Attribution (CC BY) license (https:// creativecommons.org/licenses/by/ $4.0 /)$.
1 Centre of Research in Ionic Liquids, Universiti Teknologi PETRONAS, Seri Iskandar 32610, Perak, Malaysia; fiezah_hfzh@yahoo.com (N.H.); asyrafhanim92@gmail.com (A.H.A.R.); ninna.azman@gmail.com (N.S.A.)

2 Fundamental and Applied Science Department, Universiti Teknologi PETRONAS, Seri Iskandar 32610, Perak, Malaysia; nurhusna_25111@utp.edu.my

3 UTM-MPRC Institute for Oil and Gas (IFOG), Universiti Teknologi Malaysia, Skudai 81310, Johor, Malaysia; nusaibah@utm.my

4 Department of Energy Engineering, Faculty of Engineering, School of Chemical and Energy Engineering, Universiti Teknologi Malaysia, Skudai 81310, Johor, Malaysia

* Correspondence: noraini.ghani@utp.edu.my

\begin{abstract}
This study describes the potential conversion of dried microalgae. Chlorella vulgaris (C. vulgaris) into fatty acid methyl ester (FAME) using the direct transesterification (DT) method and using ionic liquids (ILs) as a catalyst. In this work, the performance of monocationic IL, namely 1-butyl-1methylpyrrolidinium bromide (IL 1), and dicationic IL, namely 1,4-bis(1-methylpyrrolidinium-1-yl) butane dibromide (IL 2), as catalysts was compared for DT of C. vulgaris under microwave irradiation. The results revealed that IL $\mathbf{2}$ showed a better performance in catalyzing the DT reaction by producing $87.9 \mathrm{mg} / \mathrm{g} \%$ of FAME, while the use of IL 1 led to $74.3 \mathrm{mg} / \mathrm{g} \%$ of FAME under optimum conditions. The kinetic study for direct transesterification of C. vulgaris showed that the reaction followed a first order kinetic reaction where the activation energies were calculated to be $22.2499 \mathrm{~kJ} \mathrm{~mol}^{-1}$ and $22.0413 \mathrm{~kJ} \mathrm{~mol}^{-1}$ for IL 1 and IL 2, respectively.
\end{abstract}

Keywords: ionic liquids; microalgae; biodiesel; catalysts

\section{Introduction}

Biodiesel production from microalgae is one of the most significant alternative energy sources. Microalgae offer the use of non-arable land for cultivation and grow rapidly throughout the year. Thus, it makes them a perfect substitute for liquid fossil fuels with respect to the cost, renewability and environmental concerns. In addition, microalgae have high lipid productivity, which is the main essential component for biodiesel conversion [1]. In 1942, Harder and von Witsch reported that microalgae could be a feasible source of lipids which are able to serve as food and can be converted to biofuel [2]. Since then, extensive research involving microalgae and their bioproducts has been explored. The conversion of microalgae into biodiesel typically includes the dehydration of algae, lipid extraction, transesterification reaction catalyzed by homogenous acid or base catalysts and a purification process. Thus, the complexity of the process makes biodiesel production from algae expensive [3,4]. Recently, a transesterification reaction has been performed using a biocatalyst such as lipase. However, there are some limitations in their use as a catalyst in transesterification, such as lower thermal stability of the biocatalyst, lower reaction rate and high enzyme cost [5]. Therefore, it is sensible to explore more economic and feasible approaches for biodiesel production in respect to process route and the type of catalyst.

The use of the microwave (MW) irradiation method has received great interest in biodiesel production from microalgae. This process is also known as direct transesteri- 
fication (DT). DT of microalgae with the assistance of microwave is desirable to reduce processing time as well as to simplify the conversion steps and, consequently, reduce the overall cost for biodiesel production. DT is an alternative technique which facilitates the lipid conversion to alkyl esters directly, without extraction and drying process of the lipid. This method offers more energy-efficient and rapid heating in which molecules are directly heated through the interaction between microwave energy and molecular dipole moments of the starting materials [6-8]. MW energy penetrates deeply through the cell wall structure and generates a high temperature and pressure gradient, which facilitates cell wall degradation leading to higher lipid extraction. Hence, to further enhance the synergistic potential of microwave and IL in DT, two ILs were introduced in this process.

The conventional DT process typically utilizes volatile organic compounds that are harmful to the environment $[9,10]$. Hence, researchers started to explore green chemicals as a replacement, such as ionic liquids. Ionic liquids (ILs) are organic salts that consist of cations and anions with unique properties such as non-volatility and thermal stability and exhibit excellent physical characteristics that make them applicable in catalytic reactions. The use of ILs as a catalyst for biodiesel production offers an eco-friendly production route [11,12]. Ullah and co-workers reported that 3-methyl-1-(4-sulfo-butyl)$3 \mathrm{H}$-imidazolium trifluoromethanesulfonate, $(\mathrm{BSMIM})\left(\mathrm{CF}_{3} \mathrm{SO}_{3}\right)$ is a promising catalyst where it was able to catalyze transesterification reaction with high yield [13]. Furthermore, Wu et al. reported that hydrogen sulfate-based IL has converted up to $90 \%$ triglycerides for the transesterification of cottonseed oil to fatty acid methyl ester (FAME) [14].

In 2016, Wahidin and co-workers combined the benefits of the microwave method and ionic liquids (ILs) for DT of algal oils [15]. Two years after, they reported the synergistic effect of 1-ethyl-3-methylimidazolium methyl sulphate (EMIM)]( $\left.\mathrm{MeSO}_{4}\right)$ and MW using the DT technique, which exhibits $42 \%$ fatty acid methyl esters (FAME) per dry biomass weight [16]. Since limited research has been conducted so far on the use of IL-catalyzed DT of microalgae with the assistance of microwave, there is a lack of research findings and the data are still scarce. To date, most of the ILs used as catalysts in the DT reaction were imidazolium-based ILs, which are known to be expensive. In 2021, Malekghasemi and co-workers reported a good performance of phosphonium carboxylate ionic liquid, namely tetrabutylphosphonium formate, as a catalyst in the DT [17]. However, both imidazolium-based ILs and phosphonium-based ILs are found to be toxic [18]. In 2014, Neumann and co-workers reported the biodegradability properties of pyrrolidinium-based ILs [19]. Hence, considering both cost and toxicity properties, the pyrrolidinium-based ILs were chosen as the catalyst in this study. Besides that, the researchers also found that the anion and substituent on cation play a vital role in the acidic nature of ILs. Dicationic ILs possesses a higher melting point, wider liquid range and better thermal stability compared to conventional mono-cationic ILs $[20,21]$. Therefore, di-cationic ILs are potential candidates to be used as catalysts in this field. To the best of our knowledge, both mono and dicationic pyrrolidinium-based ILs have not been tested as catalysts in the DT of microalgae for FAME production. Hence, we wish to demonstrate the synergistic effect by combining microwave irradiation and the use of two types of pyrrolidinium-based ILs as catalysts for FAME production.

\section{Results and Discussion}

Owing to the biodegradability and unique properties of ILs, monocationic and dicationic pyrrolidinium-based ionic liquids, namely, 1-butyl-1-methylpyrrolidinium bromide and 1,4-bis(1-methylpyrrolidinium-1-yl) butane dibromide, were evaluated as catalysts in the FAME production under MW irradiation. The molecular structures of the synthesized ILs were confirmed using NMR and CHNS techniques. The structures of the synthesized monocationic (IL 1) and dicationic (IL 2) pyrrolidinium-based ILs are depicted in Figure 1. Meanwhile the NMR spectroscopy for both ILs were presented in Supplementary Materials (Figures S1-S4). 


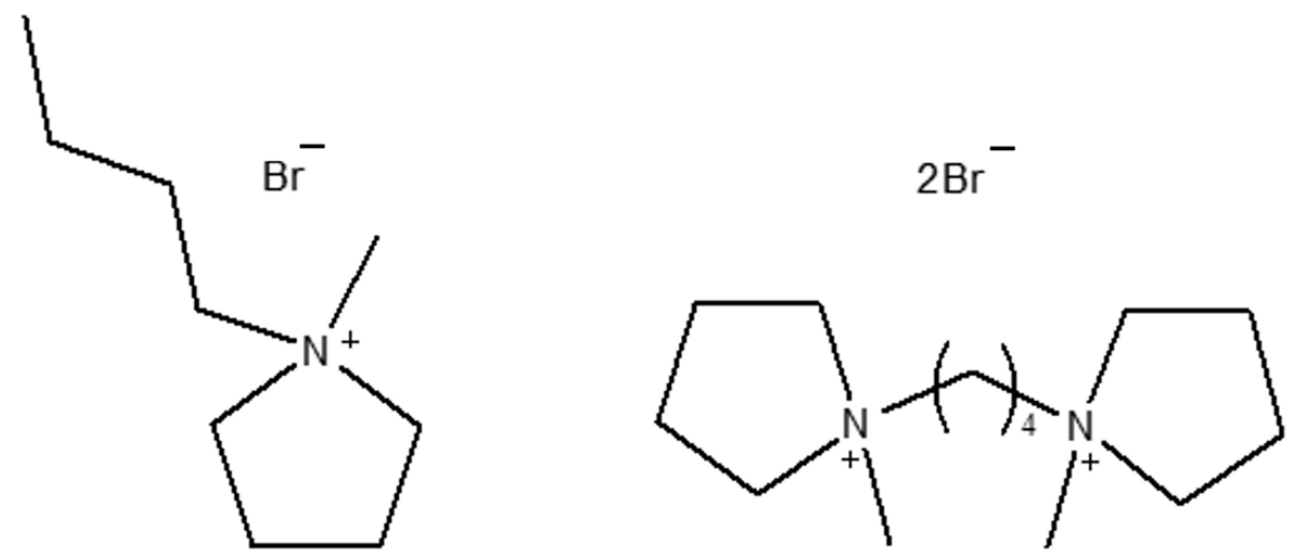

IL 1

IL 2

Figure 1. Chemical structures of the monocationic (IL 1) and dicationic (IL 2) pyrrolidinium-based ILs.

2.1. Optimization of Microalgae Conversion Using Pyrrolidinium-Based ILs:

1-Butyl-1-methylpyrrolidinium Bromide (IL 1) and 1,4-Bis(1-methylpyrrolidinium-1-yl) Butane Dibromide (IL 2)

Our previous work reported the FAME extraction from C. vulgaris using a conventional Bligh and Dyer method without the presence of IL as a catalyst, where $19.5 \mathrm{mg} / \mathrm{g} \%$ was achieved. Additionally, the transesterification of C. vulgaris with the assistance of MW without the presence of IL was also evaluated, where a higher FAME yield of $26.8 \mathrm{mg} / \mathrm{g} \%$ was achieved. The catalytic performance of pyrrolidinium based ILs was investigated for biodiesel production from dry microalgae, C. vulgaris powder by the direct transesterification reaction. Various factors such as catalyst loading, reaction time, reaction temperature and ratio of co-solvent, which may affect the transesterification reaction, were studied in detail.

To evaluate the performance of the catalyst, the amount of catalyst was varied in the range of 0.5 to $5.0 \mathrm{wt} \%$ relative to microalgae, while the other parameters were kept constant at $60^{\circ} \mathrm{C}$ and $15 \mathrm{~min}$ reaction time with a ratio of methanol to hexane at 30:0. Results obtained during this present study have been compared with conventional Bligh and Dyer and MW methods. Figure 2 shows the FAME yield obtained in the reactions carried out with different catalyst loadings. It can be observed that the FAME yield increased with the increase in IL catalysts amount. The addition of catalyst molecules increased the opportunity for the triglycerides in the microalgae to be converted to FAME [22]. The highest yields of $62.0 \mathrm{mg} / \mathrm{g} \%$ and $77.0 \mathrm{mg} / \mathrm{g} \%$ were obtained when $3.5 \mathrm{wt} \%$ IL 1 and $3.0 \mathrm{wt} \%$ IL 2 were used for the transesterification of microalgae, respectively. The di-cationic IL 2 have a better performance in catalyzing the DT at lower concentration compared to monocationic IL 1. This could be due to the higher acidity of dicationic ILs as compared to monocationic ILs, as suggested by previous reports [23,24]. A further increase in the amount of IL catalysts did not enhance the yield for both cases. This can be explained by the increase in the viscosity of the reactants mixture, thus limiting the dispersion and the mass transfer of the immiscible reactants [25]. As the high dosage of IL catalyst also led to the additional cost [26], the catalyst loading of $3.5 \mathrm{wt} \%$ IL $\mathbf{1}$ and $3.0 \mathrm{wt} \%$ IL $\mathbf{2}$ was used for the following section. 


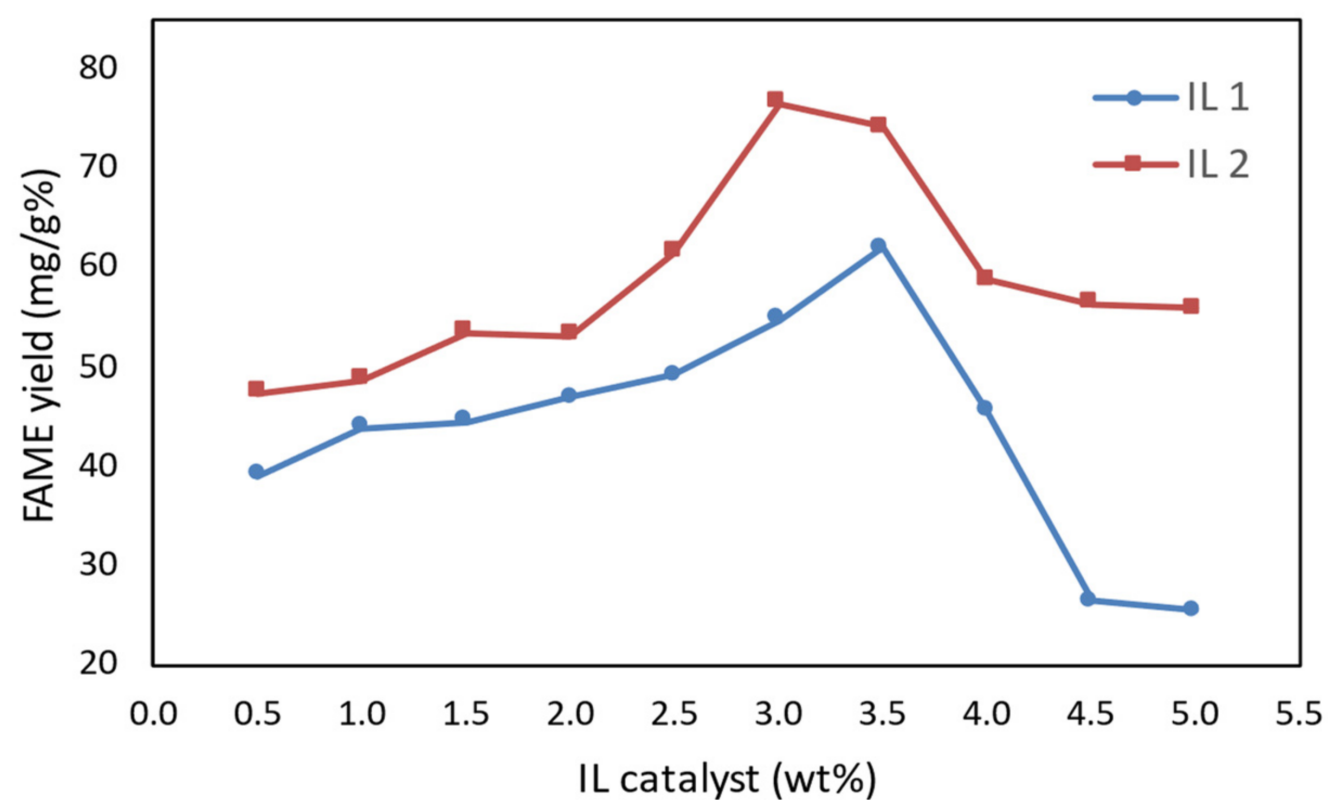

Figure 2. Effect of ILs catalyst on FAME yield.

Reaction time also plays a significant role in the transesterification of triglycerides and influences the yield of FAME. Figure 3 shows the effect of reaction time towards transesterification reaction, where the investigation was conducted by varying the reaction time from 5 to $30 \mathrm{~min}$, keeping the other parameters constant at $60{ }^{\circ} \mathrm{C}$, and the dosages of ILs catalyst were used at the optimum amount of $3.0 \mathrm{wt} \%$ and $3.5 \mathrm{wt} \%$ for IL 1 and IL 2, respectively. The experimental results showed that the FAME yield increased as the reaction time was prolonged for both ILs. The highest FAME yield was obtained at 20 min with $74.3 \mathrm{mg} / \mathrm{g} \%$ and $87.9 \mathrm{mg} / \mathrm{g} \%$ when IL 1 and IL 2 were used, respectively. However, a prolonged reaction time for both cases did not improve the performance. Hence, the optimum reaction time for both ILs was concluded to be $20 \mathrm{~min}$.

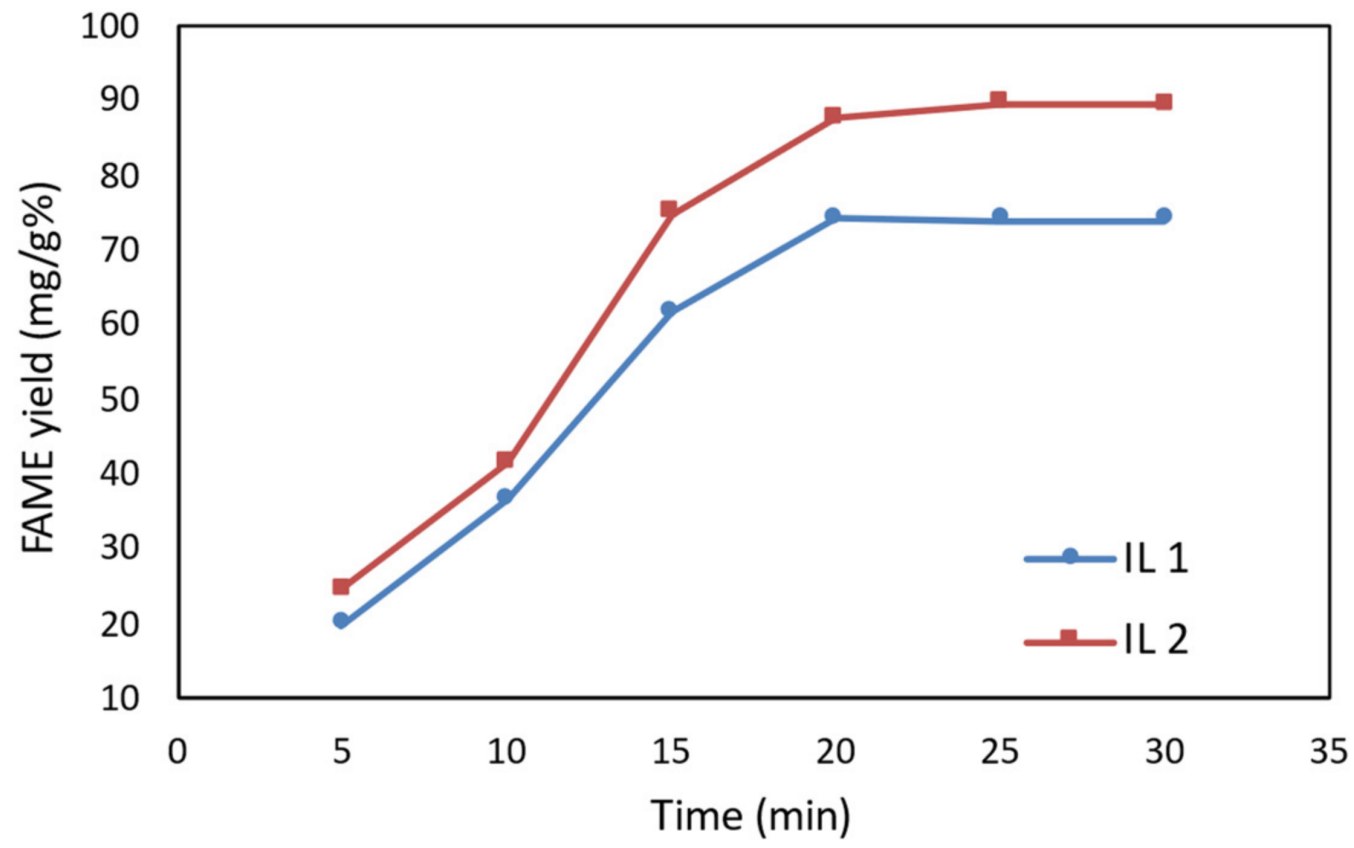

Figure 3. Effect of reaction time on FAME yield.

Temperature is one of the important factors that highly affects the yield of FAME. In this study, the reaction temperature was varied from $50{ }^{\circ} \mathrm{C}$ to $80{ }^{\circ} \mathrm{C}$, as shown in 
Figure 4. Constant dosages of ILs catalyst were used at $3.0 \mathrm{wt} \%$ and $3.5 \mathrm{wt} \%$ for IL 1 and IL 2, correspondingly. The figure showed that at $50{ }^{\circ} \mathrm{C}$, the FAME yield for the reactions catalyzed by IL 1 and IL 2 was relatively low, at only $53.1 \mathrm{mg} / \mathrm{g} \%$ and $53.9 \mathrm{mg} / \mathrm{g} \%$, respectively. However, increasing the temperature increased the FAME yield due to the rise in the reaction rate [27]. For IL 2, no further increase in yield was observed when the temperature was higher than $60^{\circ} \mathrm{C}$.

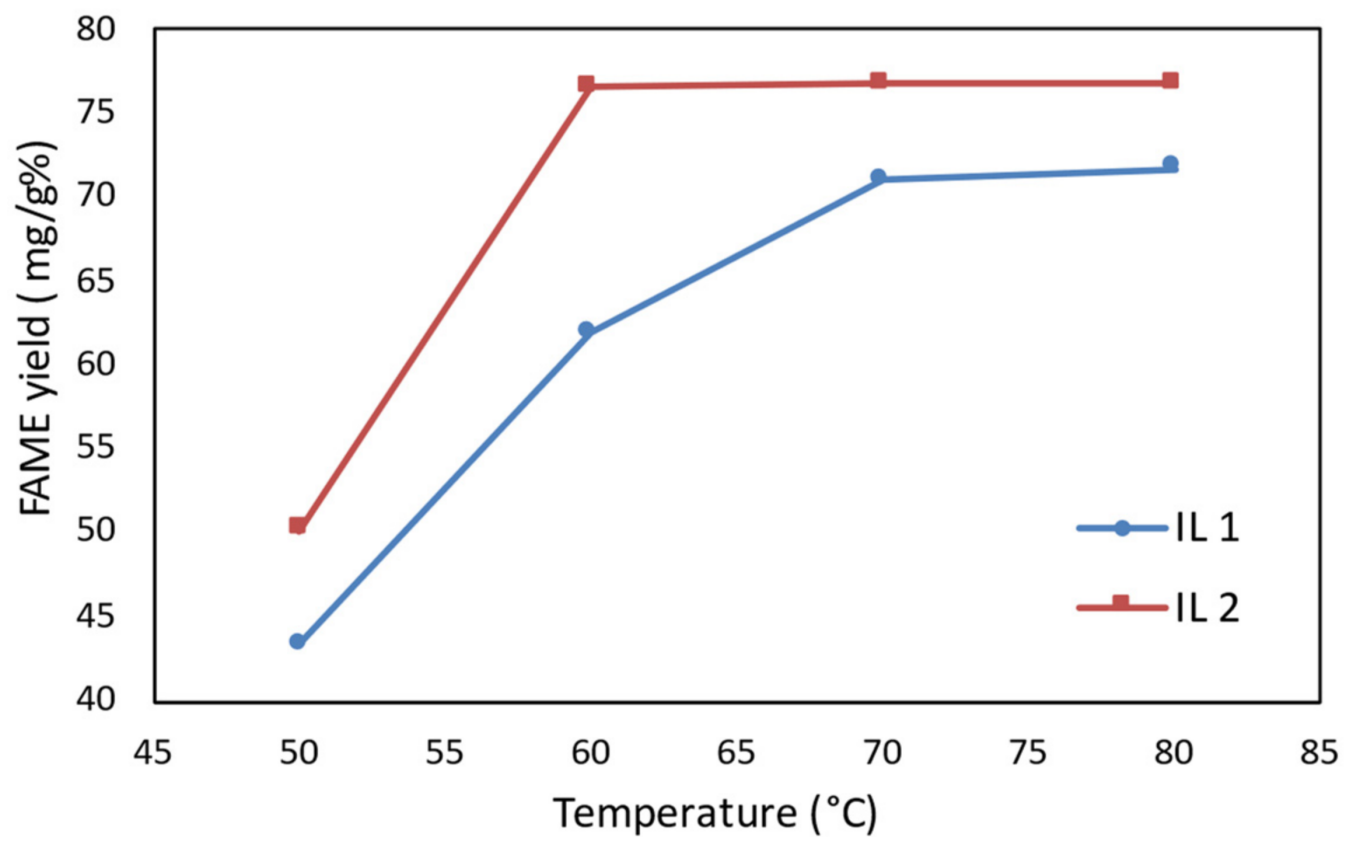

Figure 4. Effect of temperature on FAME yield.

The effect of hexane as a co-solvent along with methanol in the DT of microalgae was investigated. Figure 5 depicts that the increase in the ratio of methanol to hexane reduced the FAME yield. The result is in contrast with the findings found in other literature [28]. This can be explained by the lower contact of lipid with methanol in the presence of hexane as co-solvent. Furthermore, the excess hexane led to lower heat transfer between lipid and methanol phase, and this phenomenon caused the reduction in FAME yield [29]. The MW irradiation method offers impressive synergy with the IL catalyst, especially those performed well on the polarization phenomenon and ionic conduction mechanism [30]. Figure 5 shows that, at a higher ratio of methanol to hexane (30:10 and 30:15), the FAME yield trend was transverse for the reactions catalyzed by IL $\mathbf{1}$ and IL 2. This can be explained by the difference in polarity of IL $\mathbf{1}$ and IL 2. A high amount of hexane in the reaction system may interrupt the behavior of IL 2, which leads to the less localized orientation of molecules under MW condition, thus reducing the FAME yield. Hence, this optimum condition was further used for the kinetic studies for both ILs.

\subsection{FAME Analysis}

The FAME composition extracted from C. vulgaris using ILs as a catalyst at optimum condition was determined using GC-FID, as shown in Table 1. Palmitic acid (C16:0) was found to be the dominant fatty acid in C. vulgaris, which was in agreement with a previous report [31]. The other major composition of FAME components found in C. vulgaris after transesterification using IL 1 and IL 2 was caproic acid (C6:0), caprylic acid (C8:0), capric acid (C10:0) and cis-13,16-docosadienoic acid (C22:2). It was also observed that linoleic acid/linolelaidic acid (C18:2 C+T) was detected in GC analysis of the transesterification reaction using both ILs. 


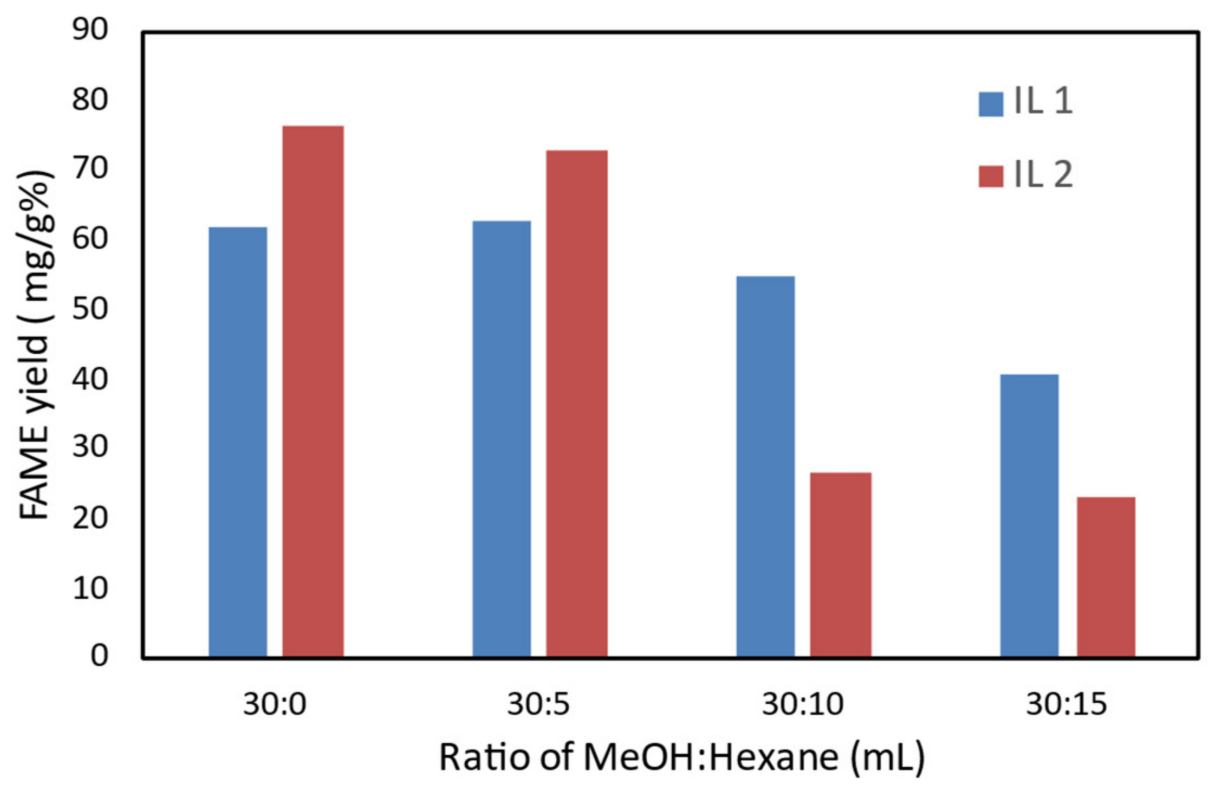

Figure 5. Effect of co-solvent on FAME yield.

Table 1. FAME components found C. vulgaris.

\begin{tabular}{llll}
\hline Name of FAME & & IL $\mathbf{1}(\mathbf{m g} / \mathbf{g} \mathbf{)})$ & IL $\mathbf{2}(\mathbf{m g} / \mathbf{g} \mathbf{)})$ \\
\hline C6:0 & Caproic acid & 14.64 & 17.68 \\
C8:0 & Caprylic acid & 11.11 & 21.46 \\
C10:0 & Capric acid & 10.03 & 7.66 \\
C11:0 & Undecanoic acid & 8.26 & 2.58 \\
C12:0 & Lauric acid & 1.28 & 0.35 \\
C13:0 & Tridecanoic acid & ND & 0.29 \\
C14:0 & Myristic acid & ND & 0.41 \\
C14:1 & Mysteroleic acid & ND & ND \\
C15:0 & Pentadecanoic acid & ND & ND \\
C15:1 & Cis,10 Pentadecanoic acid & ND & ND \\
C16:0 & Palmitic acid & 21.66 & 23.75 \\
C16:1 & Palmitoleic acid & 1.90 & 2.30 \\
C17:1 & Cis,10 Hepentadecanoic acid & 2.37 & ND \\
C18:0 & Stearic acid & ND & ND \\
C18:1 C+T & Elaidic acid + Oleic acid & ND & 2.89 \\
C18:2 C+T & Linoleic acid + Linolelaidic acid & 7.62 & 7.41 \\
C18:3n6 & y- linolenic acid & ND & 2.99 \\
C18:3n3 & Linoienic acid & 2.17 & ND \\
C20:0 & Arachidic acid & 3.22 & 2.85 \\
C20:2 & Cis-11,14-Eicosadienoic acid & ND & ND \\
C22:2 & Cis-13,16-Docosadienoic acid & 15.75 & 7.38 \\
\hline ND: & & &
\end{tabular}

ND: not detected.

\subsection{Kinetic Studies}

In the excess of methanol, the equilibrium shifts to the right (forward reaction), which was assumed to be a single step process by neglecting the intermediate reaction [32,33]. The kinetic for this DT reaction was evaluated for the kinetic first order reaction. Based on Figure 6a,b, the plot for the DT reactions using both IL 1 and IL $\mathbf{2}$ showed a high correlation coefficient in the range of 0.9776 to 0.9975 for all temperatures. Thus, it showed that the DT follow the standard kinetic order for microalgae conversion to FAME. 

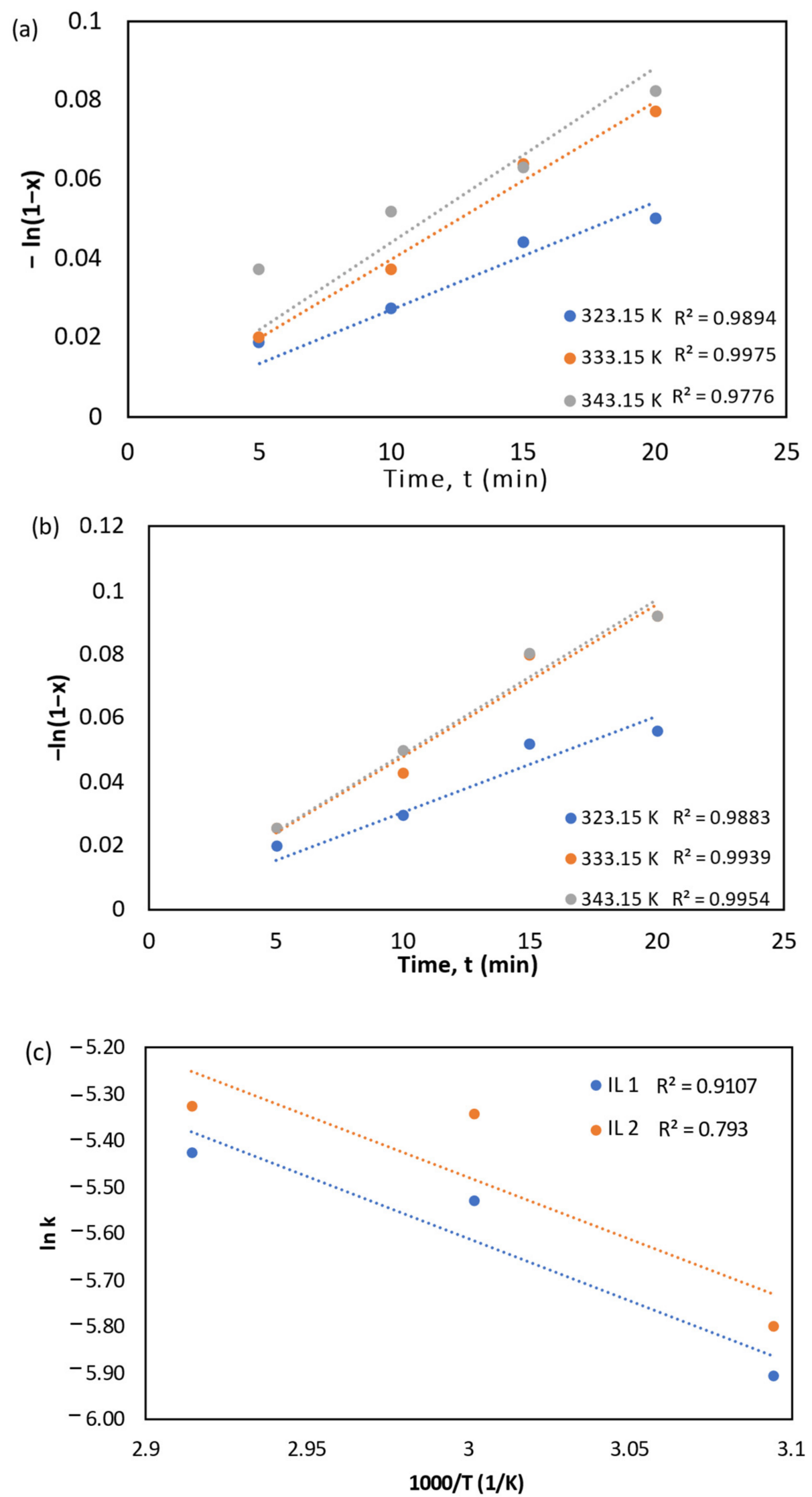

Figure 6. First order reaction for the DT of microalgae at different temperature using IL 1 (a) and IL 2 (b) and the Arrhenius plot (c) 
The use of IL 2 showed a faster reaction, where the rate constants were in the range of $0.003030 \mathrm{~min}^{-1}$ to $0.004867 \mathrm{~min}^{-1}$, as compared to the use of IL 1, where the rate constants were in the range of $0.002720 \mathrm{~min}^{-1}$ to $0.004396 \mathrm{~min}^{-1}$, as tabulated in Table 2. Figure $6 \mathrm{c}$ depicts the Arrhenius plot for the DT reactions using both IL $\mathbf{1}$ and IL 2. The figure shows that the correlation coefficients obtained for the DT using IL $\mathbf{1}$ and IL $\mathbf{2}$ were acceptable at $R^{2}=0.9107$ and $R^{2}=0.7930$, respectively. Hence, the graph was used to determine the kinetic parameters such as activation energy, Ea and pre-exponential factor, A. Table 2 tabulates the value for both kinetic parameters where the use of IL $\mathbf{2}$ showed a lower activation energy $(22.0413 \mathrm{~kJ} / \mathrm{mol})$ as compared to IL $1(\mathrm{Ea}=22.2499 \mathrm{~kJ} / \mathrm{mol})$. Thus, lower energy was required to allow the direct transesterification of microalgae to happen. Hence, in this case, with lower IL2 amount (3.0 wt\%), higher FAME yield $(87.9 \mathrm{mg} / \mathrm{g} \%$ ) was achieved. The pre-exponential factor, representing the frequency of effective collision between molecules which leads to reaction, for the DT using IL 2, was also higher than the DT using IL 1. Hence, the use of IL 2 as a catalyst was more productive and accelerated the conversion of microalgae to FAME.

Table 2. Kinetic parameters of DT reaction for microalgae.

\begin{tabular}{ccccc}
\hline & Temperature (K) & $\mathbf{k}\left(\mathbf{m i n}^{-1}\right)$ & Ea (kJ/mol) & A \\
\hline \multirow{2}{*}{ IL 1 } & 323.15 & 0.002720 & 22.2499 & 11.2099 \\
& 333.15 & 0.003970 & & 11.8580 \\
IL $\mathbf{2}$ & 343.15 & 0.004396 & 22.0413 & \\
& 33.15 & 0.003030 & & \\
\hline
\end{tabular}

This trend can be explained by the effect of ILs' structure and the involvement of the functional group of the ILs in catalyzing the DT reactions, as shown in Figure 7. Figure 7 a depicts the proposed mechanism for this IL-catalyzed DT reaction. Generally, the DT process involved several steps. The reaction started with the attack of $\mathrm{N}+$ of the pyrrolidinium cation of the IL on the carbonyl group of the ester, leading to the formation of carbocation. The reaction continued with the nucleophilic attack of the alcohol to produce the intermediate. It was followed by the removal of the first fatty acid methyl ester (FAME) and formation of diglycerides. The reaction continued with the attack of the IL cation towards diglycerides and monoglycerides to produce an overall of three FAME compounds and one glycerol. Figure $7 \mathrm{~b}$ showed the general equation for direct transesterification of triglycerides in microalgae to form fatty acid methyl ester (FAME) and glycerol as the byproduct. Various studies have described a similar mechanism for various catalysts [34,35]. Since the reaction was initiated by the cation, the higher amount of positively-charged atoms available in the cation would increase the speed of the reaction, as revealed by the finding of this study. 
<smiles>[R]C(=O)OCC(COC([R])=O)OC([R])=O</smiles>

(Triglyceride)<smiles>[R3]C(=O)OCC(COC([R3])[R4])OC([R])=O</smiles><smiles>[R]C(=O)OCC(COC([R])[R])OC([R])=O</smiles>

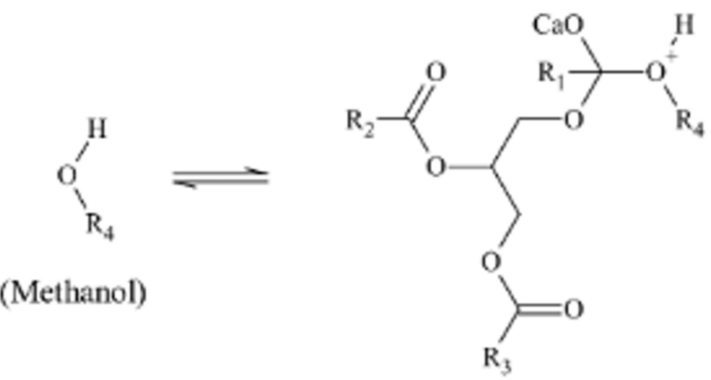<smiles>[R]C(=O)OCC(COC([R])([2H])[O-])OC([R])=O</smiles><smiles>C=CC=C</smiles><smiles>[R]C(=O)OCC(CO)OC([R])=O</smiles>

(Diglyceride)<smiles>CCCC[N+]1(C)CCCC1</smiles>

(Cation)<smiles>C[C-]CC[N+]1(C)CCCC1</smiles>

(a) Proposed mechanism for IL-catalyzed direct transesterification reaction<smiles>[R]C(=O)OCC(COC([R])=O)OC([Y8])=O</smiles>

(Triglyceride)<smiles>[R3]OC([R3])=O</smiles><smiles>[CH+][18OH]</smiles>

(Methanol)<smiles>[R9]OC([R3])=O</smiles>

(FAME)

(b) General equation for transesterification of triglyceride to form FAME and glycerol

Figure 7. Proposed schematic representation of TG and methanol mechanism by pyrrolidinium-based IL as a catalyst, (a) the proposed mechanism for IL-catalyzed DT reaction, (b) the general equation for DT of TG to form FAME and glycerol as the by-product. 


\section{Materials and Methods}

\subsection{Materials}

All solvents and chemical reagents were purchased from Merck, Darmstadt, Germany and used without any purification. The CAS number, source and grade of the chemicals are as follows: 1-bromobutane (109-65-9, Merck, 99\%), 1-methylpyrrolidine (120-94-5, Merck, 98\%), 1,4-dibromobutane (110-51-1, Merck, 99\%), 2-propanol (67-63-0, Merck, 99.5\%) and diethyl ether (60-29-7, Merck, 99.9\%). Dried microalgae biomass Chlorella vulgaris (C. vulgaris) powder was purchased from a China Lover Store.

\subsection{Preparations of Catalysts}

Both ILs were synthesized using the procedure described by Burrel and co-workers [36]. The first, 1-butyl-1-methylpyrrolidinium bromide (IL 1), was synthesized by slowly adding an equimolar of 1-bromobutane $(8.05 \mathrm{~g}, 0.059$ mole) into a round bottom flask containing methylpyrrolidine ( $5 \mathrm{~g}, 0.059$ mole). The reaction was conducted under solventless condition. The mixture was stirred at $150 \mathrm{rpm}$ under reflux at $40^{\circ} \mathrm{C}$ for $24 \mathrm{~h}$. After the reaction, the mixture was left to cool at room temperature, resulting to yellowish mixture. Then, it was washed three times with $15 \mathrm{~mL}$ of diethyl ether to remove unreacted reactants. After that, the resulting slightly yellowish thick liquid IL was dried in a vacuum oven for $24 \mathrm{~h}$ (89.9\%). ${ }^{1} \mathrm{H}$ NMR (500 MHz, D $\left.\mathrm{O}\right):$ 8 3.40-3.37 (m, 4H), 3.23-3.19 (m, 2H), 2.92 (s, 3H), 2.09 $(\mathrm{m}, 4 \mathrm{H}), 1.69-1.62(\mathrm{~m}, 2 \mathrm{H}), 1.31-1.23(\mathrm{~m}, 2 \mathrm{H}), 0.83(\mathrm{t}, 3 \mathrm{H}, \mathrm{J}=7.5 \mathrm{~Hz})$ (Figure S1). ${ }^{13} \mathrm{C}$ NMR $\left(125 \mathrm{MHz}, \mathrm{D}_{2} \mathrm{O}\right): \delta=14.04,19.78,21.59,25.46,48.23,63.42,64.06$ (Figure S2). Theoretical calculation (\%): C, 48.66; H, 9.07; N, 6.30, Experimental: C, 49.06; H, 9.17; N, 6.55.

For 1,4-bis(1-methylpyrrolidinium-1-yl) butane dibromide (IL 2), an equimolar of 1,4dibromobutane (10.8 $\mathrm{g}, 0.05$ mole) was slowly added into a round bottom flask containing methylpyrrolidine $(4.3 \mathrm{~g}, 0.05$ mole $)$ in 2-propanol $(50 \mathrm{~mL})$ while being stirred at $150 \mathrm{rpm}$. The mixture was refluxed at $70{ }^{\circ} \mathrm{C}$ for $24 \mathrm{~h}$. After the reaction, the mixture was left to cool at room temperature. Then, 2-propanol was removed using a rotary evaporator, resulting in a highly viscous dark brown mixture. After that, it was washed three times with $15 \mathrm{~mL}$ diethyl ether before being dried under vacuum and yielding a solid product $(86.0 \%) .{ }^{1} \mathrm{H}$ NMR (500 MHz, D $2 \mathrm{O}){ }^{1} \mathrm{H}$ NMR (500 MHz, $\left.\mathrm{D}_{2} \mathrm{O}\right): \delta 3.58-3.38(\mathrm{~m}, 12 \mathrm{H}), 3.08(\mathrm{~s}, 6 \mathrm{H}), 2.24(\mathrm{~m}$, $8 \mathrm{H}), 1.98-1.96$ (m, $4 \mathrm{H})$ (Figure S3). ${ }^{13} \mathrm{C}$ NMR $\left(125 \mathrm{MHz}, \mathrm{D}_{2} \mathrm{O}\right) \delta=19.32,21.72,48.97,63.37$, 64.09 (Figure S4). Theoretical calculation (\%): C, 43.54; H, 7.83; N, 7.25. Experimental: C, 43.63; H, 8.31; N, 7.65.

\subsection{Transesterification of Microalgae to Fatty Acid Methyl Ester (FAME)}

\subsubsection{Conventional Transesterification Reaction}

For comparison purposes, the conventional Bligh and Dyer method was conducted without the presence of IL as a catalyst. First, $1 \mathrm{~g}$ of $\mathrm{C}$. vulgaris was dissolved in a mixture of methanol, chloroform and water with a ratio of 1:2:0.8 $(30 \mathrm{~mL})$ for $2 \mathrm{~h}$. Then, $10 \mathrm{~mL}$ of hexane was added and centrifuged at $4000 \mathrm{rpm}$ for $15 \mathrm{~min}$ where two layers were formed. The top layer, which was the hexane layer, was separated, and hexane was removed completely using a rotary evaporator. The mass of lipid was weighed after the hexane had been removed. For the transesterification step, $1 \mathrm{~mL}$ of chloroform was added. Methanolysis was conducted at $60^{\circ} \mathrm{C}$ for $3 \mathrm{~h}$. The sample was further dried at $75^{\circ} \mathrm{C}$ for $30 \mathrm{~min}$ and cooled to room temperature. Then, $0.3 \mathrm{~mL}$ of chloroform and $0.7 \mathrm{~mL}$ of heptane were added into the sample. The sample was then filtered and transferred into the vials. Finally, $1 \mathrm{~mL}$ of methyl heptadecanoate (C17:0) was added to the vial as a GC reference, and the sample was further analyzed by GC-FID.

\subsubsection{Direct Transesterification Reaction}

The direct transesterification (DT) reactions were conducted in a Milestone Flexi Wave microwave (MW) system. The experiments were conducted under microwave irradiation with exiting power of $700 \mathrm{~W}$. To begin, $1 \mathrm{~g}$ of dried microalgae (C. vulgaris) was added into $30 \mathrm{~mL}$ of methanol/hexane solution containing the pre-determined amount of ionic 
liquid in MW vessel. Then, the solution was exposed to microwave irradiation power. The biodiesel was then filtered through $0.22 \mu \mathrm{m}$ nylon syringe filter for further FAME analysis. To note, in the case of a transesterification reaction involving 30:0 methanol to hexane ratio (which means no hexane was involved during the reaction), an extra step was added before the FAME analysis. N-hexane was used to separate the FAME from the residual.

\subsubsection{FAME Analysis}

The biodiesel samples obtained by the DT reaction were analyzed by an Agilent 7890A gas chromatograph system equipped with a J\&W DB-WAX column $(30 \mathrm{~m} \times 0.25 \mathrm{~mm}$, $0.25 \mu \mathrm{m}$ thickness) with helium as the carrier gas. The flow rate of the carrier gas was set at $1.2 \mathrm{~mL} / \mathrm{min}$. One $\mu \mathrm{L}$ of the sample was injected, and the inlet was maintained at $250{ }^{\circ} \mathrm{C}$. The oven was heated up from $50^{\circ} \mathrm{C}$ to $220^{\circ} \mathrm{C}$ for $10 \mathrm{~min}$ with $10^{\circ} \mathrm{C} / \mathrm{min}$ intervals. Then, the temperature was further increased to $250^{\circ} \mathrm{C}$ for $10 \mathrm{~min}$ with $5^{\circ} \mathrm{C} / \mathrm{min}$ interval. The temperature of the injector and detector were set at $250{ }^{\circ} \mathrm{C}$. Methyl heptadeconate (C17:0) was used for internal standard for the quantification of the compounds. A Supelco 37-component mixture was used as the external standard to quantify the final product Figures S5 and S6 present chromatogram of Supelco 37-component and the FAME sample (IL 1) at $60{ }^{\circ} \mathrm{C}, 20 \mathrm{~min}$, in $30 \mathrm{~mL}$ of $\mathrm{MeOH}$ and 3.0\% wt of IL). The mass and percentage of FAME yield were calculated using the following equations:

$$
\begin{gathered}
m_{\text {FAME }}=\frac{A_{\text {FAME }}-A_{I S}}{A_{\text {IS }}} \times C_{\text {IS }} \times V_{\text {IS }} \\
\text { FAME yield }\left(\frac{\mathrm{mg}}{\mathrm{g}} \%\right)=\frac{\text { weight of FAME obtained after DT }(\mathrm{mg})}{\text { weight ofalgae input }(\mathrm{g})} \times 100 \%
\end{gathered}
$$

where $A_{\text {FAME }}$ is the total peak area of FAME, $A_{I S}$ is the peak area of the internal standard (methyl heptadecanoate), $C_{\text {IS }}$ is the concentration $(\mathrm{mg} / \mathrm{L})$ of the internal standard and $V_{\text {IS }}$ is the volume $(\mathrm{mL})$ of the internal standard.

\subsection{Kinetic Studies}

The transesterification reaction involved the conversion of triglyceride (TG) in biodiesel feedstock, which, in this case, was microalgae to fatty acid methyl ester (FAME), which is the required biodiesel. Stoichiometrically, 3 moles of alcohol and 1 mole of TG are required to afford 3 moles of methyl ester (ME) and 1 mole of glycerol (GL) as the by-product. In general, this reaction consists of three consecutive reversible reactions, but with the excess use of methanol, the reaction is simplified as a single step forward reaction (Equation (3)).

$$
\mathrm{TG}+3 \mathrm{MeOH} \rightarrow 3 \mathrm{ME}+\mathrm{GL}
$$

Thus, in this work, the transesterification reaction kinetics were calculated only for the forward reaction, following a first-order reaction, as a similar approach applied in other literature $[26,36]$. The rate of reaction is dependent only on the TG concentration, and the methanol concentration is assumed to be constant. The reverse reaction can be neglected, and the rate equation can be written as in Equation (4).

$$
-r=\frac{d[\mathrm{TG}]}{d t}=k[\mathrm{TG}]
$$

Generally, in the case of microalgae, the conversion of microalgae to FAME is used to monitor the kinetic of the reaction. Thus, the equation of conversion (Equation (5)) is considered. Rearranging the equation in terms of triglyceride concentration leads to Equation (6).

$$
\begin{gathered}
x=\frac{[\mathrm{TG}]_{0}-[\mathrm{TG}]}{[\mathrm{TG}]_{0}} \\
{[\mathrm{TG}]=[\mathrm{TG}]_{0}(1-x)}
\end{gathered}
$$


Thus, Equation (4) can be transformed into Equation (7). Integrating Equation (7) leads to Equation (8).

$$
\begin{gathered}
\frac{d x}{d t}=k[1-x] \\
-\ln (1-x)=k t
\end{gathered}
$$

where $k$ is the rate constant, $x$ is the conversion of the microalgae to FAME, $[\mathrm{TG}]_{0}$ is the initial concentration of triglyceride, which in this case is the microalgae, and [TG] is the triglyceride (microalgae) concentration at time $t$. The data obtained from the conversion of triglycerides at different temperatures condition were used to find the rate constant $k$ by plotting the graph of $-\ln (1-x)$ versus reaction time (Figure $6 a, b)$. The rate constant was then used to obtain the activation energy by applying the Arrhenius equation (Equation (9)) to plot the Arrhenius graph (Figure 6c).

$$
k=A e^{\left(\frac{-E_{a}}{R T}\right)}
$$

where $k\left(\mathrm{~min}^{-1}\right)$ is the rate constant, $A$ is the pre-exponential factor, $R$ is the universal gas constant, $E_{a}$ is the activation energy and $T$ is the absolute temperature $(\mathrm{K})$.

\section{Conclusions}

In the present study, we combined two environmentally benign methods, which were the use of microwave and ionic liquids (ILs), to assist the direct transesterification (DT) of microalgae to FAME. Monocationic and dicationic pyrrolidinium-based IL were synthesized and applied as a catalyst. The optimized conditions for the FAME production from microalgae were reactions conducted at $60^{\circ} \mathrm{C}$ in $20 \mathrm{~min}$ with a catalyst dosage of $3.5 \mathrm{wt} \%$ and $3.0 \mathrm{wt} \%$ for IL 1 and IL 2 to produce $74.3 \mathrm{mg} / \mathrm{g} \%$ and $87.9 \mathrm{mg} / \mathrm{g} \%$ of FAME yields, respectively. The kinetic study demonstrated that the reaction followed a first order kinetic reaction with the activation energy, Ea of $22.2499 \mathrm{~kJ} \mathrm{~mol}^{-1}$ for DT using IL 1 and $22.0413 \mathrm{~kJ} \mathrm{~mol}^{-1}$ for DT using IL 2. Thus, the use of IL $\mathbf{2}$ was favorable as compared to IL 1. From this study, it can be concluded that the synergistic effect from ILs and microwave irradiation showed a beneficial method where only a small amount of ILs was required to act as a catalyst in the DT of microalgae to biodiesel.

Supplementary Materials: The following supporting information can be downloaded at: https: / / www.mdpi.com/article/10.3390/catal12030277/s1, Figure S1: ${ }^{1} \mathrm{H}$ NMR of IL 1; Figure S2: ${ }^{13} \mathrm{C}$ NMR of IL 1; Figure S3: ${ }^{1} \mathrm{H}$ NMR of IL 2; Figure S4: ${ }^{13} \mathrm{C}$ NMR of IL 2; Figure S5: Chromatogram of the 37 Component FAME mix obtained using GC-FID equipment with a DB-Wax column.; Figure S6: GC chromatogram for the characterization of the FAME sample (IL 1) at $60{ }^{\circ} \mathrm{C}, 20 \mathrm{~min}$, in $30 \mathrm{~mL}$ of $\mathrm{MeOH}$ and $3.0 \%$ wt of IL).

Author Contributions: Conceptualization, N.A.G.; Data curation, N.H., A.H.A.R., N.S.A. and N.A.R.; Methodology, N.H., A.H.A.R. and N.S.A.; Project administration, N.A.G. and N.H.; Writing—original draft, N.H. and A.H.A.R.; Writing-review and editing, N.A.G. and A.N.M. All authors have read and agreed to the published version of the manuscript.

Funding: This research was funded by Yayasan Universiti Teknologi PETRONAS (YUTP), grant number 015LC0-049.

Data Availability Statement: Not applicable.

Acknowledgments: The authors are grateful to the Centre of Research in Ionic Liquids (CORIL), Universiti Teknologi PETRONAS, Perak, Malaysia for the research facilities.

Conflicts of Interest: The authors declare no conflict of interest. The funders had no role in the design of the study; in the collection, analyses, or interpretation of data; in the writing of the manuscript, or in the decision to publish the results. 


\section{References}

1. Singh, J.; Gu, S. Commercialization potential of microalgae for biofuels production. Renew. Sustain. Energy Rev. 2010, 14, 2596-2610. [CrossRef]

2. Harder, R.; von Witsch, H. Über Massenkultur von Diatomeen. Ber. Dtsch. Bot. Ges. 1942, 60, 146-152.

3. Sun, Y.; Cooke, P.; Reddy, H.K.; Muppaneni, T.; Wang, J.; Zeng, Z.; Deng, S. 1-Butyl-3-methylimidazolium hydrogen sulfate catalyzed in-situ transesterification of Nannochloropsis to fatty acid methyl esters. Energy Convers. Manag. 2017, 132, 213-220. [CrossRef]

4. Chen, C.-L.; Huang, C.-C.; Ho, K.-C.; Hsiao, P.-X.; Wu, M.-S.; Chang, J.-S. Biodiesel production from wet microalgae feedstock using sequential wet extraction/transesterification and direct transesterification processes. Bioresour. Technol. 2015, 194, 179-186. [CrossRef] [PubMed]

5. Rizwanul Fattah, I.M.; Ong, H.C.; Mahlia, T.M.I.; Mofijur, M.; Silitonga, A.S.; Rahman, S.M.; Ahmad, A. State of the art of catalysts for biodiesel production. Front. Energy Res. 2020, 8, 101. [CrossRef]

6. Zheng, H.; Yin, J.; Gao, Z.; Huang, H.; Ji, X.; Dou, C. Disruption of Chlorella vulgaris cells for the release of biodiesel-producing lipids: A comparison of grinding, ultrasonication, bead milling, enzymatic lysis, and microwaves. Appl. Biochem. Biotechnol. 2011, 164, 1215-1224. [CrossRef] [PubMed]

7. Lee, J.-Y.; Yoo, C.; Jun, S.-Y.; Ahn, C.-Y.; Oh, H.-M. Comparison of several methods for effective lipid extraction from microalgae. Bioresour. Technol. 2010, 101, S75-S77. [CrossRef]

8. Patil, P.D.; Gude, V.G.; Mannarswamy, A.; Cooke, P.; Munson-McGee, S.; Nirmalakhandan, N.; Lammers, P.; Deng, S. Optimization of microwave-assisted transesterification of dry algal biomass using response surface methodology. Bioresour. Technol. 2011, 102, 1399-1405. [CrossRef] [PubMed]

9. Hasnain, M.; Abideen, Z.; Naz, S.; Roessner, U.; Munir, N. Biodiesel production from new algal sources using response surface methodology and microwave application. Biomass Convers. Biorefin. 2021, 1-16. [CrossRef]

10. Shrikhande, S.; Deshpande, G.; Sawarkar, A.N.; Ahmad, Z.; Patle, D.S. Design and retrofitting of ultrasound intensified and ionic liquid catalyzed in situ algal biodiesel production. Chem. Eng. Res. Des. 2021, 171, 168-185. [CrossRef]

11. Piemonte, V.; Di Paola, L.; Iaquaniello, G.; Prisciandaro, M. Biodiesel production from microalgae: Ionic liquid process simulation. J. Clean. Prod. 2016, 111, 62-68. [CrossRef]

12. Ong, H.C.; Tiong, Y.W.; Goh, B.H.H.; Gan, Y.Y.; Mofijur, M.; Fattah, I.R.; Chong, C.T.; Alam, M.A.; Lee, H.V.; Silitonga, A. Recent advances in biodiesel production from agricultural products and microalgae using ionic liquids: Opportunities and challenges. Energy Convers. Manag. 2020, 228, 113647. [CrossRef]

13. Ullah, Z.; Bustam, M.A.; Man, Z.; Khan, A.S.; Muhammad, N.; Sarwono, A.; Farooq, M.; Ullah, R.; Mengal, A.N. A detail description on catalytic conversion of waste palm cooking oil into biodiesel and its derivatives: New functionalized ionic liquid process. ChemistrySelect 2017, 2, 8583-8595. [CrossRef]

14. Wu, Q.; Chen, H.; Han, M.; Wang, D.; Wang, J. Transesterification of cottonseed oil catalyzed by Brønsted acidic ionic liquids. Ind. Eng. Chem. Res. 2007, 46, 7955-7960. [CrossRef]

15. Wahidin, S.; Idris, A.; Shaleh, S.R.M. Ionic liquid as a promising biobased green solvent in combination with microwave irradiation for direct biodiesel production. Bioresour. Technol. 2016, 206, 150-154. [CrossRef] [PubMed]

16. Wahidin, S.; Idris, A.; Yusof, N.M.; Kamis, N.H.H.; Shaleh, S.R.M. Optimization of the ionic liquid-microwave assisted one-step biodiesel production process from wet microalgal biomass. Energy Convers. Manag. 2018, 171, 1397-1404. [CrossRef]

17. Malekghasemi, S.; Kariminia, H.R.; Plechkova, N.K.; Ward, V.C. Direct transesterification of wet microalgae to biodiesel using phosphonium carboxylate ionic liquid catalysts. Biomass Bioenergy 2021, 150, 106126. [CrossRef]

18. Hossain, M.I.; Samir, B.B.; El-Harbawi, M.; Masri, A.N.; Mutalib, M.A.; Hefter, G.; Yin, C.Y. Development of a novel mathematical model using a group contribution method for prediction of ionic liquid toxicities. Chemosphere 2011, 85, 990-994. [CrossRef] [PubMed]

19. Neumann, J.; Steudte, S.; Cho, C.W.; Thöming, J.; Stolte, S. Biodegradability of 27 pyrrolidinium, morpholinium, piperidinium, imidazolium and pyridinium ionic liquid cations under aerobic conditions. Green Chem. 2014, 16, 2174-2184. [CrossRef]

20. Sun, H.; Zhang, D.; Liu, C.; Zhang, C. Geometrical and electronic structures of the dication and ion pair in the geminal dicationic ionic liquid 1, 3-bis [3-methylimidazolium-yl] propane bromide. J. Mol. Struct. THEOCHEM 2009, 900, 37-43. [CrossRef]

21. Qiao, L.; Li, H.; Shan, Y.; Wang, S.; Shi, X.; Lu, X.; Xu, G. Study of surface-bonded dicationic ionic liquids as stationary phases for hydrophilic interaction chromatography. J. Chromatogr. A 2014, 1330, 40-50. [CrossRef] [PubMed]

22. Panchal, B.; Chang, T.; Qin, S.; Sun, Y.; Wang, J.; Bian, K. Optimization of soybean oil transesterification using an ionic liquid and methanol for biodiesel synthesis. Energy Rep. 2020, 6, 20-27. [CrossRef]

23. Khan, A.S.; Man, Z.; Bustam, M.A.; Kait, C.F.; Nasrullah, A.; Ullah, Z.; Sarwono, A.; Ahamd, P.; Muhammad, N. Dicationic ionic liquids as sustainable approach for direct conversion of cellulose to levulinic acid. J. Clean. Prod. 2018, 170, 591-600. [CrossRef]

24. Li, Y.; Hu, S.; Cheng, J.; Lou, W. Acidic ionic liquid-catalyzed esterification of oleic acid for biodiesel synthesis. Chin. J. Catal. 2014, 35, 396-406. [CrossRef]

25. Xie, W.; Wang, H. Synthesis of heterogenized polyoxometalate-based ionic liquids with Brönsted-Lewis acid sites: A magnetically recyclable catalyst for biodiesel production from low-quality oils. J. Ind. Eng. Chem. 2020, 87, 162-172. [CrossRef] 
26. Ding, H.; Ye, W.; Wang, Y.; Wang, X.; Li, L.; Liu, D.; Gui, J.; Song, C.; Ji, N. Process intensification of transesterification for biodiesel production from palm oil: Microwave irradiation on transesterification reaction catalyzed by acidic imidazolium ionic liquids. Energy 2018, 144, 957-967. [CrossRef]

27. Masri, A.N.; Mutalib, M.A.; Aminuddin, N.F.; Lévêque, J.M. Novel $\mathrm{SO}_{3} \mathrm{H}$-functionalized dicationic ionic liquids-A comparative study for esterification reaction by ultrasound cavitation and mechanical stirring for biodiesel production. Sep. Purif. Technol. 2018, 196, 106-114. [CrossRef]

28. Ruppel, T.; Huybrighs, T.; Shelton, C. Fatty Acid Methyl Esters in B100 Biodiesel by Gas Chromatography (Modified EN 14103); Perkin Elmer's Application Note: Shelton, CT, USA, 2008.

29. Andrade, T.A.; Errico, M.; Christensen, K.V. Influence of the reaction conditions on the enzyme catalyzed transesterification of castor oil: A possible step in biodiesel production. Bioresour. Technol. 2017, 243, 366-374. [CrossRef] [PubMed]

30. Gude, V.G.; Patil, P.; Martinez-Guerra, E.; Deng, S.; Nirmalakhandan, N. Microwave energy potential for biodiesel production. Sustain. Chem. Processes 2013, 1, 5. [CrossRef]

31. Demirbas, A.; Demirbas, M.F. Importance of algae oil as a source of biodiesel. Energy Convers. Manag. 2011, 52, 163-170. [CrossRef]

32. Sivakumar, P.; Sindhanaiselvan, S.; Gandhi, N.N.; Devi, S.S.; Renganathan, S. Optimization and kinetic studies on biodiesel production from underutilized Ceiba Pentandra oil. Fuel 2013, 103, 693-698. [CrossRef]

33. Csernica, S.N.; Hsu, J.T. The phase behavior effect on the kinetics of transesterification reactions for biodiesel production. Ind. Eng. Chem. Res. 2012, 51, 6340-6349. [CrossRef]

34. Ullah, Z.; Khan, A.S.; Muhammad, N.; Ullah, R.; Alqahtani, A.S.; Shah, S.N.; Ghanem, O.B.; Bustam, M.A.; Man, Z. A review on ionic liquids as perspective catalysts in transesterification of different feedstock oil into biodiesel. J. Mol. Liq. 2018, 266, 673-686. [CrossRef]

35. Long, T.; Deng, Y.; Gan, S.; Chen, J. Application of choline chloride $x \mathrm{ZnCl}_{2}$ ionic liquids for preparation of biodiesel. Chin. J. Chem. Eng. 2010, 18, 322-327. [CrossRef]

36. Burrell, A.K.; Del Sesto, R.E.; Baker, S.N.; McCleskey, T.M.; Baker, G.A. The large scale synthesis of pure imidazolium and pyrrolidinium ionic liquids. Green Chem. 2007, 9, 449-454. [CrossRef] 